\title{
DAPUR SEBAGAI DASAR PENATAAN RUANG DALAM MEMPERTAHANKAN KONDISI TERMAL HUNIAN DI DAERAH DINGIN
}

\author{
Debby Budi Susanti \\ Dosen Prodi Arsitektur, Fak. Teknik Sipil dan Perencanaan, ITN Malang \\ e-mail: budisusantidebby@gmail.com \\ Gaguk Sukowiyono \\ Dosen Prodi Arsitektur, Fak. Teknik Sipil dan Perencanaan, ITN Malang \\ e-mail: gaguksukowiyono@yahoo.com
}

\begin{abstract}
ABSTRAK
Dapur merupakan salah satu ruang yang tidak bisa dihilangkan keberadaannya dalam sebuah rumah tinggal. Fungsi utama sebuah ruang dapur dalam sebuah rumah tinggal adalah sebagai tempat memasak dan menyiapkan makanan. Dalam perkembangannya saat ini, dapur tidak hanya berfungsi sebagai tempat memasak saja, tetapi anggota keluarga lainnya juga seringkali berkumpul dan mengobrol di dalam ruang dapur. Hal ini merupakan pengaruh dari kondisi kenyamanan termal yang ada di dalam ruang dapur. Sama halnya dengan wilayah Kecamatan Poncokusumo, Kabupaten Malang berada di ketinggian $\pm 600-1200 \mathrm{~m}$ di atas permukaan laut dengan curah hujan rata-rata $2300-2500 \mathrm{~mm}$ per tahun dengan suhu rata-rata $21.7^{\circ} \mathrm{C}$ dan kelembaban relatif $75-98 \%$. Hal ini menggambarkan bahwa kondisi lingkungan daerah tersebut berhawa dingin sehingga sangat berpengaruh terhadap kenyamanan termal huniannya. Sumber panas yang berada pada tungku ruang dapur merupakan unsur penunjang kondisi kenyamanan termal yang ada dalam hunian di daerah dingin. Hal ini yang kemudian menjadi pusat penataan ruang-ruang lainnya dalam sebuah rumah tinggal. Dalam perolehan data obyek penelitian dilakukan observasi lapangan terhadap pengukuran kondisi luar dan dalam selanjutnya disimulasikan dan dianalisa secara diskriptif serta dikaji dengan dukungan data pustaka dan hasil penelitian yang pernah dilakukan.
\end{abstract}

Kata kunci: dapur, kenyamanan termal, penataan ruang

ABSTRACT

The kitchen is one of space that cannot be eliminated in a residential house. The main function of a kitchen space in a house is as a place to cook and prepare food. In its current development, the kitchen does not only function as a cooking place, but other family members also often gather and chat in the kitchen room. This is an influence from the thermal comfort 
conditions in the kitchen room. Similar to Poncokusumo Subdistrict, Malang Regency is at an altitude of \pm 600-1200 $\mathrm{m}$ above sea level with an average rainfall of $2300-2500 \mathrm{~mm}$ per year with an average temperature of $21.7^{\circ} \mathrm{C}$ and a relative humidity of $75-98 \%$. This illustrates that the environmental conditions of the area are cold so it is very influential on the thermal comfort of the occupancy. The heat source in the kitchen room furnace is an element supporting the thermal comfort conditions that exist in residential areas in cold areas. This then became another center for spatial planning in a residential house. In obtaining research object data, field observations were carried out on the measurement of external and internal conditions which were then simulated and analyzed descriptively and studied with the support of library data and the results of research that had been carried out.

Keywords: kitchen, thermal comfort, spatial planning

\section{PENDAHULUAN}

Manusia selalu berusaha untuk membuat hunian tempat tinggalnya terasa nyaman dalam menunjang semua aktifitasnya ketika berada di rumah. Kondisi sebuah hunian sangat ditentukan oleh kebutuhan pemiliknya. Sehingga kondisi hunian selalu berbeda antara yang satu dengan yang lain. Hal ini akan terlihat pada hunian pada masyarakat yang dibangun secara pribadi (pemukiman tradisional). Kondisi ini berbeda dengan hunian yang dibangun secara massal oleh developer.

Kemampuan manusia untuk tinggal dan beradaptasi dengan lingkungan sekitarnya juga turut menentukan kondisi hunian yang dimilikinya. Membahas tentang lingkungan, tidak bisa lepas dari pembahasan tentang manusia beserta komponen-komponen alam yang mengelilinginya. Manusia tidak bisa hidup sendiri tanpa adanya dukungan dari lingkungan di sekitarnya, baik lingkungan alami dan lingkungan binaan, serta lingkungan fisik maupun lingkungan non-fisik. Semuanya turut mempengaruhi pola perilaku kehidupan manusia yang membutuhkan interaksi dengan lingkungan sekitarnya.

Penentu dari kondisi fisik hunian selain faktor budaya, faktor penting lainnya yang harus dipertahankan adalah kondisi kenyamanan termal di dalam hunian. Karena secara harfiahnya manusia dapat beradaptasi dalam batas suhu tertentu saja. Faktor kenyamanan termal bangunan turut mempengaruhi kondisi fisik hunian, mulai dari bentuk bangunan, penataan ruang, sampai dengan pemilihan material bangunan. Kondisi lingkungan alam yang berbeda pada setiap wilayah menyebabkan tuntutan penyesuaian kondisi fisik bangunan.

Kondisi zona nyaman suhu udara dalam ruangan di Indonesia berkisar antara 22,5-26 ${ }^{\circ} \mathrm{C}$ (Kotta, Husni : 2008). Sehingga pada hunian di daerah

PAWON: Jurnal Arsitektur, Nomor -- Volume --, Bulan Tahun, ISSN 2597-7636 
dingin penghuni rumah membutuhkan elemen ruangnan yang dapat berfungsi sebagai penghangat. Wilayah Kecamatan Poncokusumo Kabupaten Malang berada pada ketinggian $\pm 600-1200 \mathrm{~m}$ di atas permukaan laut dengan curah hujan rata-rata $2300-2500 \mathrm{~mm}$ per tahun dengan suhu rata-rata $17^{\circ} \mathrm{C}$ hingga $21.7^{\circ} \mathrm{C}$ dan kelembaban rata-rata antara $75 \%$ hingga $95 \%$. Kecepatan angin per tahun berkisar antara $\pm 3-5$ $\mathrm{m} / \mathrm{s}$. Hal ini menggambarkan bahwa kondisi lingkungan daerah tersebut berhawa dingin sehingga sangat berpengaruh terhadap kenyamanan rumah tinggalnya. Salah satu penunjang penghangat yang umumnya terdapat dalam sebuah hunian adalah ruang dapur. Sehingga posisi ruang dapur seringkali dijadikan sebagai pusat dari aktifitas dan penataan ruang yang ada dalam hunian.

Tujuan dari penelitian ini adalah untuk mempelajari sejauh mana peranan ruang dapur dapat mempengaruhi penataan ruang hunian dalam upaya untuk mempertahankan kondisi kenyamanan termal bagi penghuninya, terutama pada hunian di daerah dingin.

\section{TINJAUAN PUSTAKA}

Dapur dalam bahasa Jawa disebut pawon, mengandung dua pengertian pertama, bangunan rumah yang khusus disediakan untuk kegiatan masakmemasak dan kedua, da-pat diartikan tungku. Kata pawon berasal dari kata dasar awu yang berarti abu, mendapat awalan-pa dan akhiran-an, yang berarti tempat. Dengan demikian, pawon (pa+awu+an) yang berarti tempat awu atau abu. Dalam budaya Jawa menurut Pasurdi Suparlan, konsep tentang sistem klasifikasi mengenai alam semesta dan isinya terdapat konsep dikotomi antara yang baik dan buruk, bersih dan kotor. Oleh karena itu dalam sistem klasifikasi itu ma-ka kakus (jamban atau kamar kecil) maupun dapur letaknya selalu di belakang. Oleh karena dapur dianggap tempat kotor, maka dalam hal membuat bangunan dapur tidak begitu diperhatikan seperti halnya kalau membuat rumah induk. Menurut Daldjoeni (1985) pada umumnya bangunan dapur adalah bangunan tambahan, dan biasanya bangunan dapur di-buat sesudah bangunan rumah selesai. Dapur atau pawon sebagai bangunan tambahan, tidak dianggap sebagai bangunan pokok atau penting, dan konstruksi bangunan dapur sangat sederhana. Oleh karena itu untuk membuat dapur tidak diperlukan persyaratan yang rumit seperti akan membuat rumah induk yang memerlukan perhitungan waktu (primbon).

Menurut Koentjaraningrat, terdapat kepercayaan pada orang Jawa bahwa dapur adalah bagian rumah yang paling lemah disebabkan dapur merupakan tempat perempuan, dan perempuan dianggap mahkluk yang paling lemah atau disebut liyu Arti kata liyu, dalam Bausastra JawaIndonesia (1980), dapat diartikan capai atau lelah. Dari arti kata ini dapat dimaknai bahwa bekerja di dapur akan capai/lelah. Dalam membuat dapur

PAWON: Jurnal Arsitektur, Nomor 01 Volume 3, Bulan Januari-Juni Tahun 2019, ISSN 2597-7636 
atau pawon ada yang masih menggunakan perhitungan-perhitungan Jawa. Misalnya, oleh karena dapur dianggap sebagai tempat perempuan maka untuk membangun dapur harus dimulai saat neptune nyaine (hari pasaran kelahiran istri), misalnya Senin Pon, Selasa Wage dan sebagainya. Supaya dalam menggunakan dapur diberi keselamatan, ada juga yang menggunakan perhitungan yaitu jatuh tiba lara ( $t i b a=$ jatuh, lara $=$ mati), jadi dapur atau pawon diartikan sebagai tempat barang mati, atau tempat buangan.

Dalam budaya jawa, Pawon atau dapur tradisional dalam budaya Jawa merupakan representasi dari tata kehidupan sehari-hari masyarakat Jawa, baik dari tata letaknya, fung-sinya, dan isinya. Pawon atau dapur tradisional juga menegaskan adanya deskriminasi seks dalam pembagian kerja.

Indonesia termasuk negara yang beriklim tropis lembab. Karakteristik iklim tropis lembab mempunyai derajat kelembaban dan curah hujan yang tinggi. Dampak dari kondisi tersebut adalah banyak terdapat bukaan dan naungan berupa sosoran. Sepanjang tahun mempunyai temperatur rata-rata yang tinggi, sehingga memepengaruhi bangunan mempunyai bukaan yang mempertimbangkan aliran udara. Kondisi tersebut berhubungan dengan diurnal yang rendah ser $8^{\circ} \mathrm{C}$, akibat variasi temperatur yang rendah. Radiasi matahari bervariasi dengan kondisi sering berawan.

Kondisi iklim tropis lembab memerlukan syarat-syarat khusus dalam perancangan bangunan dan lingkungan binaan, mengingat ada beberapa factor- faktor spesifik yang hanya dijumpai secara khusus pada iklim tersebut, sehingga teori-teori arsitektur, komposisi, bentuk, fungsi bangunan, citra bangunan dan nilai-nilai estetika bangunan yang terbentuk akan sangat berbeda dengan kondisi yang ada di wilayah lain yang berbeda kondisi iklimnya.

Usaha untuk mendapatkan kenyamanan thermal terutama adalah mengurangi perolehan panas, memberikan aliran udara yang cukup dan membawa panas keluar bangunan serta mencegah radiasi panas, baik radiasi langsung matahari maupun dari permukaan dalam yang panas. Perolehan panas dapat dikurangi dengan menggunakan bahan atau material yang mempunyai tahan panas yang besar, sehingga laju aliran panas yang menembus bahan tersebut akan terhambat. Permukaan yang paling besar menerima panas adalah atap. Sedangkan bahan atap umumnya mempunyai tahanan panas dan kapasitas panas yang lebih kecil dari dinding. Untuk mempercepat kapasitas panas dari bagian atas agak sulit karena akan memperberat atap. Tahan panas dari bagian atas bangunan dapat diperbesar dengan beberapa cara, misalnya rongga langitlangit, penggunaan pemantul panas reflektif juga akan memperbesar tahan panas.

Karakteristik utama pada iklim tropis lembab menurut Evans (1980) antara lain mempunyai fluktuasi suhu udara rata-rata harian dan tahunan relatif kecil. Dengan tidak adanya perbedaan yang signifikan pada suhu 
udara dan kelembaban udara pada dua musim dan dua waktu (siang dangan malam), menjadikan kondisi lingkungan sepanjang hari tidak nyaman (discomfort). Hal ini berakibat pada proses evaporasi (berkeringat) pada permukaan kulit tubuh manusia yang tidak mudah dihapus karena tingginya suhu udara dan kelembaban udara yang terjadi akibat tingginya intensitas radiasi matahari yang disertai dengan kondisi langit yang berawan sepanjang tahun.

Untuk memperoleh kondisi kenyamanan termal pada bangunan di daerah berhawa dingin sistem struktur dan konstruksi bangunan mempunyai peran sangat penting dalam memprotek kondisi lingkungan luar, selain itu aliran panas dari luar (panas matahari) maupun dari dalam (rancangan perapian, manusia, peralatan, elemen bangunan) merupakan salah satu faktor penentu dalam terjadinya kondisi termal. Selain itu pemakaian material bangunan diupayakan dapat menahan panas diwaktu siang hari untuk dilepas pada malam hari (tahanan besar dan hantaran besar).

Adapun suhu udara panas dalam bangunan dapat dihasilkan dari panas perapian yang terletak dalam ruang pawaon, sehingga tuntutan kenyaman termal dalam bangunan dapat terpenuhi. Besar kecilnya tingkat panas yang masuk ke bangunan sangat ditentukan oleh sifat, jenis, dan karakter dari material penghantar panas yang digunakan sebagai penghasil panas.

Kondisi nyaman menurut ASHRAE, adalah kenyamanan termal seseorang yang mengekspresikan kepuasan terhadap lingkungan termal, yang dalam konteks sensasi digambarkan sebagai kondisi dimana seseorang tidak merasakan kepanasan maupun kedinginan pada lingkungan tertentu. Faktor-faktor yang mempengaruhi menurut Allard (1998) adalah lingkungan secara fisik (physical environment) dan non-fisik (non- physical environment).

\section{METODE PENELITIAN}

Data dibedakan menjadi 2 (dua) yaitu: data primer dan data sekunder. Data primer adalah data yang diperoleh langsung di lapangan, sedangkan data sekunder adalah data yang melengkapi data primer yang diperoleh dari instansi terkait berupa buku/dokumen/catatan yang diteliti atau suatu hasil penelitian.

Untuk mendapatkan data yang tepat dan dapat mendukung proses analisis, maka ada beberapa hal yang perlu diperhatikan dalam pengambilan data, yaitu: menentukan faktor pengaruh, menentukan jenis data apa yang dibutuhkan, menentukan sumber-sumber data yang relevan, menentukan cara mendapatkan data dan alat yang digunakan untuk mendapatkan data tersebut.

Bahan yang dikumpulkan dan selanjutnya digunakan dalam melakukan penelitian ini adalah sebagai berikut:

- Sketsa perkembangan denah rumah.

PAWON: Jurnal Arsitektur, Nomor 01 Volume 3, Bulan Januari-Juni Tahun 2019, ISSN 2597-7636 
- Sketsa interior ruang dapur.

- Sketsa elemen bukaan dalam rumah.

- Wawancara dengan pemilik rumah.

Obyek penelitian yang dikaji adalah ruang dapur yang digunakan tidak hanya untuk aktivitas memasak saja tetapi juga aktivitas lain, serta posisinya berada di daerah yang mudah dijangkau dari arah akses hunian dan terlihat langsung dari luar. Obyek tersebut dipilih karena dianggap memiliki kondisi yang berbeda dari pola peletakan pawon pada Arsitektur Jawa asli, dimana biasanya pawon diletakkan pada area yang sulit dijangkau dari luar. Pengamatan obyek penelitian juga dilihat bagaimana peranan posisi ruang dapur untuk pengaturan peletakan ruang lainnya. Selain itu juga diteliti ruangan dapur dapat mempertahankan kenyamanan termal hunian.

\section{HASIL DAN PEMBAHASAN}

\section{Aktivitas Sehari-Hari Warga}

Aktivitas sehari-hari warga sebagian besar dihabiskan di area sawah atau ladang karena sebagian besar warga bermata pencaharian sebagai petani atau buruh tani. Aktivitas mereka di dalam rumah dimulai lagi ketika sudah pulang dari sawah atau ladangnya, yaitu sekitar pukul 13.00 WIB. Aktivitas yang biasa dilakukan warga setelah pulang dari bekerja di sawah atau ladang adalah beristirahat sambil bercengkerama dengan keluarga.

Alasan yang mendasari dapur tersebut menjadi pusat berkumpul ialah karena fungsi dari dapur tersebut yang sangat dekat dengan ruang makan sehingga kegiatan memasak dan sarapan menjadi satu ruang. Kondisi dapur yang cenderung hangat di pagi hari dikarenakan minim-nya ventilasi udara pada dapur sehingga mengakibatkan sirkulasi udara dingin lebih lambat masuk ke dalam dapur. Kegiatan berkumpul biasa dilakukan pada waktu makan, waktu bersantai hingga berkumpulnya kerabat dan saudara pada saat musim lebaran.

Memanfaatkan perapian yang ada di ruang dapur sebagai media penghangat sudah menjadi kebiasaan warga sekitar. Melihat kondisi wilayah sekitar yang berudara dingin, tak hayal jika tungku yang berbahan bakar kayu dijadikan sebagai media untuk menghangatkan diri sekaligus menaikan suhu didalam rumah. Mayoritas warga berpendapat jika mereka seringkali memanfaatkan suhu hangat di ruang dapur tersebut untuk menghangatkan diri. Mayoritas warga pada dusun ini lebih memilih untuk datang menghampiri sumber panas ketimbang mereka membiarkan energi panas tersebut menyebar keseluruh bagian rumah. Hal ini didasarkan dari pola-pola ruang yang terbentuk pada rumah warga. Mereka sengaja memposisikan ruang-ruang privatnya berdekatan dengan ruang pawon untuk dapat menikmati suhu hangat yang bersumber dari ruang dapur tersebut di dalam ruang tempat anggota keluarga beristirahat dan berkumpul.

Pada Gambar 1 terlihat bahwa posisi dapur selalu diletakkan pada area yang berdekatan dengan ruangan tempat anggota keluarga berkumpul, bercengkerama dan beristirahat. Ruang dapur dianggap sebagai ruangan yang dapat menunjang kenyamanan termal hunian. Kondisi ruang dapur yang selalu hangat karena ada perapian dianggap sebagai ruangan yang sesuai untuk dijadikan sumber termal bagi ruang hunian. 


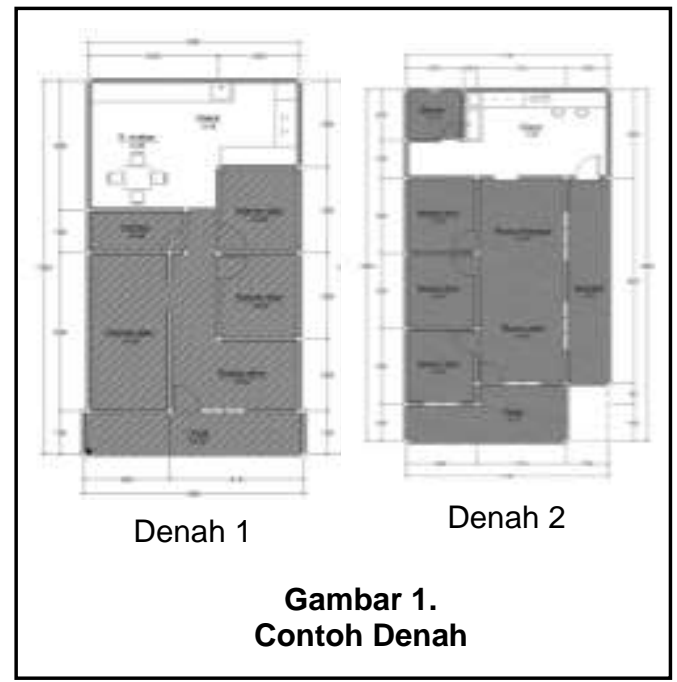

Sebagian besar masyarakat di Kecamatan Poncokusumo, Kabupaten Malang memiliki mata pencaharian sebagai petani atau buruh tani di ladang atau sawah sekitar tempat tinggalnya. Aktivitas yang dilakukan mereka di dapur diawali pagi hari ketika bangun tidur dan menyiapkan makan pagi bagi anggota keluarganya. Kondisi ruang dapur yang hangat karena pengaruh tungku atau perapian di ruang dapur merupakan sumber penghasil termal di dalam hunian.

Keluaran suhu yang diakibatkan oleh pengoperasian dapur berperan sekali dalam meningkatkan suhu di dalam rumah. Besar tidaknya pengaruh yang diberikan tergantung pada posisi dapur terhadap rumah. Letak dapur tersebut mempengaruhi sekali pola sebaran dan konsentrasi penghangatan yang terjadi pada rumah.

Sebagian besar masyarakat di daerah Kecamatan Poncokusumo, Kabupaten Malang masih menggunakan 2 (dua) macam perapian, yaitu tungku yang masih menggunakan bahan bakar kayu dan kompor gas yang sudah menggunakan bahan bakar elpiji. Tungku yang menggunakan bahan bakar kayu biasanya dimanfaatkan sebagai tempat berkumpul dan bersenda gurau ketika anggota keluarga berkumpul di rumah. Bahkan ada sebagian masyarakat yang mempunyai kebiasaan juga untuk menemui tamunya di ruang dapur.

Kondisi ruang dapur yang bersifat non formal dianggap sebagai ruang yang nyaman untuk berkumpul karena terkesan lebih santai dan kekeluargaan bila dibandingkan dengan ruangan lainnya. Sehingga ruang-ruang yang digunakan untuk beristirahat anggota keluarga diletakkan berdekatan dan mudah dijangkau dari ruang dapur.

Selain itu fungsi ruang dapur sebagai ruang untuk mengolah dan menyiapkan makanan juga merupakan salah satu faktor yang menjadikan ruang dapur harus mudah dijangkau dari ruang-ruang lain di dalam sebuah hunian.

Memanfaatkan pawon sebagai media penghangat sudah menjadi kebiasaan warga sekitar. Melihat kondisi wilayah sekitar yang berudara dingin, tak hayal jika pawon dijadikan sebagai media untuk menghangatkan diri sekaligus menaikan suhu didalam rumah. Mayoritas warga berpendapat jika mereka seringkali menggunakan pawon tersebut untuk menghangatkan diri. Namun sedikit warga yang 
menggunakannya untuk menurunkan suhu rumah. Mayoritas warga pada dusun ini lebih memilih untuk datang menghampiri sumber panas ketimbang mereka membiarkan energi panas tersebut menyebar keseluruh bagian rumah. Hal ini didasarkan dari pola-pola ruang yang terbentuk pada rumah warga, yang mana pola tata ruang rumah mereka beberapa diantara nya ada yang membiarkan udara panas dari pawon untuk dapat menyebar keseluruh bagian ruang ada juga yang tidak. Sebagian diantaranya yang tidak lebih.

\section{Kondisi Fisik Bangunan dan Dapur}

Kondisi bangunan pada lokasi penelitian sebagian besar sudah bersifat permanen dengan menggunakan material dari bahan batu bata dan kayu. Sedangkan untuk bahan penutup lantai terbuat dari keramik dan plesteran semen. Sifat bahan akan sangat menentukan dalam terciptanya tingkat kenyamanan di dalam bangunan, kemampuan bahan dalam merespon kondisi lingkungan luar harus sesuai, apakah bahan tersebut dapat cepat melepas dan menyerap panas atau lambat dalam menyerap dan melepas panas, hal ini tergantung pada konstruksi dari bahan tersebut. Semakin tebal dan padat konstuksi suatu bahan, maka semakin lambat dalam merespon kondisi lingkungan. Dengan pemilihan material bangunan yang terbuat dari bahan permanen diharapkan mampu mempertahankan kondisi termal bangunan agar tidak mudah terpengaruh kondisi udara di luar rumah dengan temperatur udara yang lebih rendah dan kelembaban udara yang tinggi.

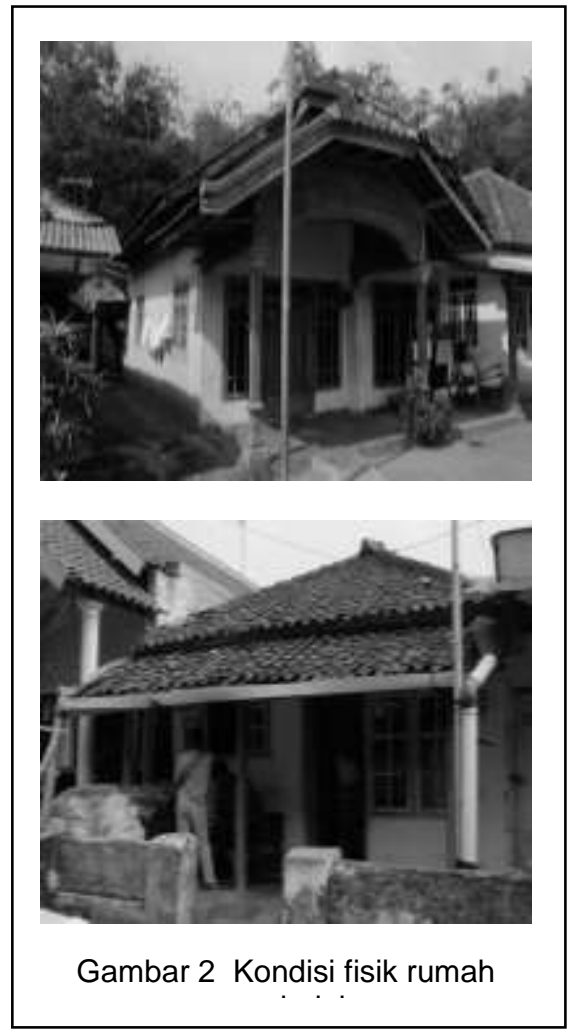

PAWON: Jurnal Arsitektur, Nomor -- Volume --, Bulan Tahun, ISSN 2597-7636 
Pada Gambar 2, terlihat kondisi rumah penduduk yang memiliki kondisi fisik yang sudah permanen dengan penutup lantai dari bahan plesteran semen. Masyarakat di lokasi penelitian berpendapat bahwa dengan penutup lantai dari bahan plesteran semen mampu menahan naiknya kelembaban yang tinggi dan suhu udara yang cenderung rendah dari luar rumah.

Pada rumah-rumah di daerah Kecamatan Poncokusumo pada umumnya memiliki jarak antara lantai dengan plafond yang tidak terlalu tinggi, dengan ketinggian maksimal $3 \mathrm{~m}$. Hanya sedikit rumah penduduk yang memiliki ketinggian jarak antara plafond dan lantai rumah yang lebih dari $3 \mathrm{~m}$. Aktifitas para ibu di dalam ruangan dapur dengan rentang waktu yang cukup panjang, yaitu mulai bangun tidur pagi sampai dengan siang hari menyebabkan udara panas yang dihasilkan dari tungku di dapur terperangkap di dalam rumah sampai saat malam hari. Sensasi udara yang dihasilkan dari tungku dapur sebagai akibat dari kondisi itu membuat sensasi udara hangat di dalam rumah yang menjadikan kenyamanan termal di dalam rumah dapat dinikmati oleh seluruh anggota keluarga ketika saatnya mereka beraktifitas di dalam rumah.

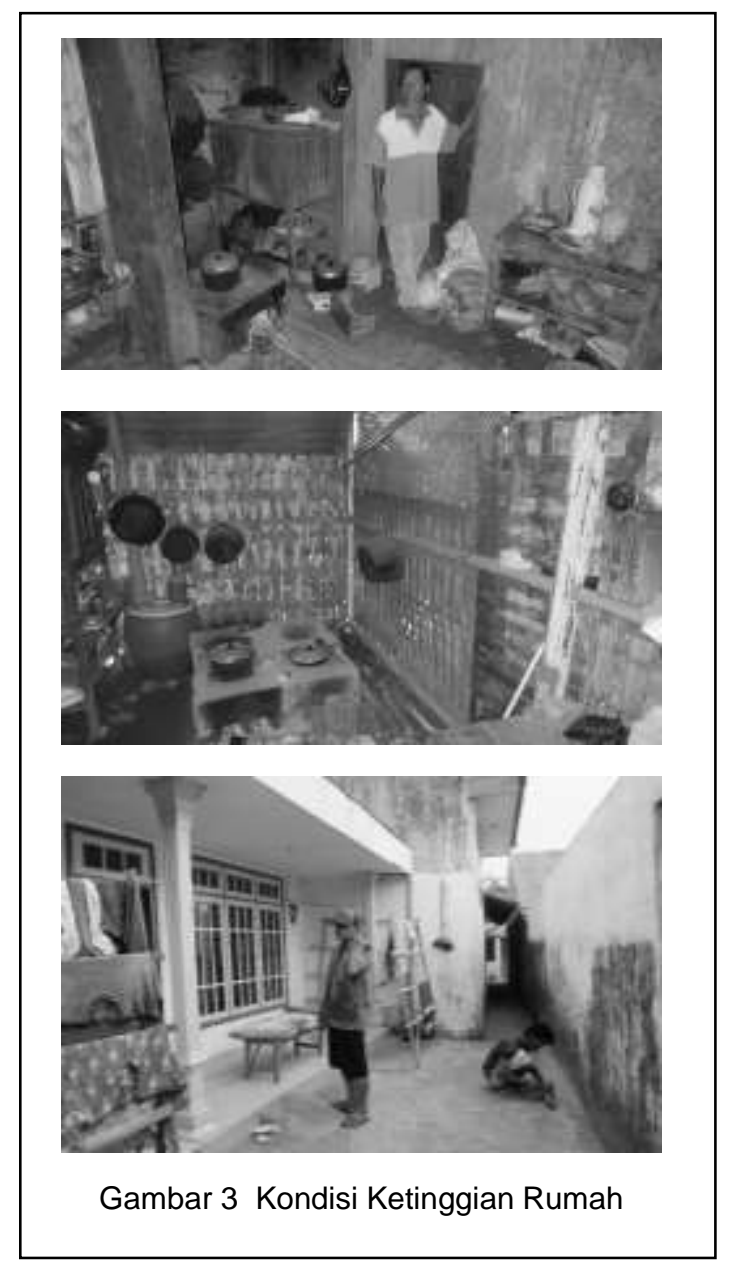

PAWON: Jurnal Arsitektur, Nomor 01 Volume 3, Bulan Januari-Juni Tahun 2019, ISSN 2597-7636 
Dalam mencapai kenyamanan termal yang lebih baik, menurut Fisk (1981) diduga manusia membentuk adaptasi dan transformasi pada lingkungannya secara tidak sadar, berdasarkan pengalamannya terhadap panas. Sehingga dalam mencapai kenyamanan manusia akan berupaya melakukan aktivitas di dalam ruang atau mencari tempat yang memungkinkan untuk memperoleh kenyamanan, dimana panas tidak dirasakan. Demikian juga dengan kondisi rumah penduduk di wilayah Kecamatan Poncokusumo. Mereka mengatur kondisi fisik rumahnya agar nyaman bagi penghuninya. Sebagian besar rumah penduduk di daerah sana mengatur posisi ruang dapur menyatu dengan rumah induknya. Hanya sekitar $40 \%$ dari jumlah rumah responden yang memisahkan ruang dapur dengan rumah induk, dengan alasan karena kondisi ruang dapur yang cenderung terlihat kotor dan agar asap yang dihasilkan dari tungku di ruang dapur tidak mengganggu udara di dalam rumah. Untuk dapur dengan kondisi demikian biasanya mempunyai bukaan yang luas sehingga aliran udara dari luar dan ke dalam memiliki sirkulasi yang lancar. Berbeda dengan ruang dapur yang menyatu dengan ruang induk. Rumah dengan ruang dapur yang demikian biasanya memiliki jumlah bukaan yang minim. Sehingga pemilik rumah sengaja membuat udara panas yang dihasilkan dari tungku ruang dapur mulai pagi hari sampai siang hari terperangkap di dalam rumah dan membuat kondisi temperatur udara di dalam rumah menjadi hangat sampai malam hari. Hal ini juga disebabkan karena masyarakat di sana terbiasa memakai baju atau pakaian dari bahan yang tipis selama beraktifitas di dalam rumah. Sehingga untuk menghangatkan tubuhnya mereka cenderung mengharapkan efek udara panas dari tungku di ruang dapur.

Tidak heran pula bahwa masyarakat di sana lebih suka berkumpul, makan dan bercengkerama di daerah dapur. Sehingga mereka biasa menggabungkan ruang dapur dengan ruang makan atau bahkan dengan ruang keluarga sekalipun. Jadi area ruang dapur dapat dikatakan juga sebagai salah satu ruang penting bagi kegiatan bersosialisasi masyarakat di lokasi penelitian. Sesuai dengan kecenderungan bahwa orang atau sekelompok lebih memilih untuk berkumpul dan bersosialisasi di area yang dianggap memiliki kondisi nyaman dan tidak terlalu formal, sehingga terkesan lebih santai dan akrab. Hal ini juga disebabkan karena tradisi masyarakat di daerah pedesaan yang lebih menyukai aktifitas berkelompok daripada aktifitas individu seperti yang lazim dilakukan masyarakat di daerah perkotaan.

Arah hadap bangunan sangat berpengaruh terhadap sirkulasi angin dan pencahayaan alami suatu bangunan. Berdasarkan pengamatan di Kecamatan Poncokusumo sebagian besar rumah warga memiliki rumah dengan arah hadap ke barat dengan presentase $50 \%$ disusul dengan arah hadap utara dengan presentase $40 \%$ sedangkan arah hadap selatan dengan presentase $10 \%$. Arah hadap rumah warga tersebut diakibatkan oleh ketersediaan lahan yang mampu mereka beli ataupun didapat dari warisan secara turun temurun sehingga kurang memperhatikan faktor pengaruh arah hadap terhadap sirkulasi udara dan pencahayaan alami.

Arah hadap rumah juga berpengaruh terhadap sirkulasi udara yang berdampak pada kenaikan atau penurunan suhu baik di luar ruangan maupun di dalam ruangan. Mengingat posisi geografis Kecamatan Poncokusumo berada di iklim tropis yang memiliki tingkat kelembaban yang tinggi dan perubahaan cuaca yang cukup signifikan ketika siang hari dan malam hari. Dikarenakan sebagian rumah

PAWON: Jurnal Arsitektur, Nomor -- Volume --, Bulan Tahun, ISSN 2597-7636 
yang memiliki arah hadap ke barat memiliki kecenderungan terkena paparan sinar matahari secara langsung ketika sore hari

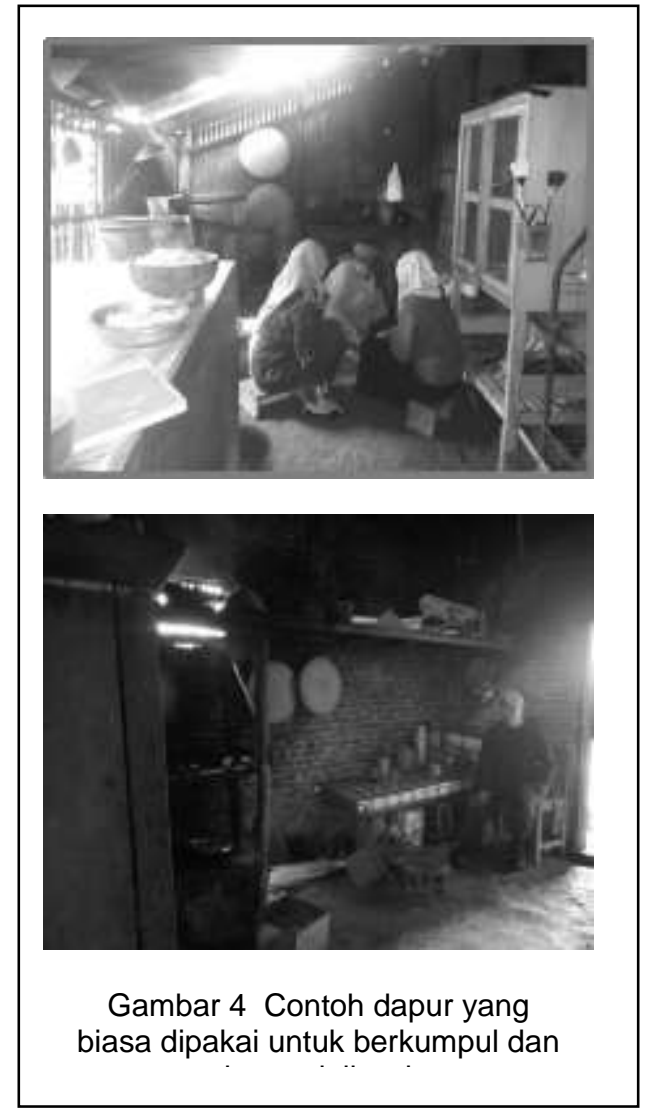

\section{Pengaruh Ruang Dapur Terhadap Suhu Bangunan}

Kondisi temperatur udara di dalam rumah juga ditentukan oleh kondisi bukaan yang ada di dalam rumah. Besar tidaknya pengaruh yang diberikan tergantung pada jumlah bukaaan rumah. Letak dapur tersebut mempengaruhi sekali pola sebaran dan konsentrasi penghangatan yang terjadi pada rumah. Pada kasus dilapangan kami menemukan perbedaan suhu yang cukup signifikan antara suhu diluar rumah dengan suhu di dalam rumah. 


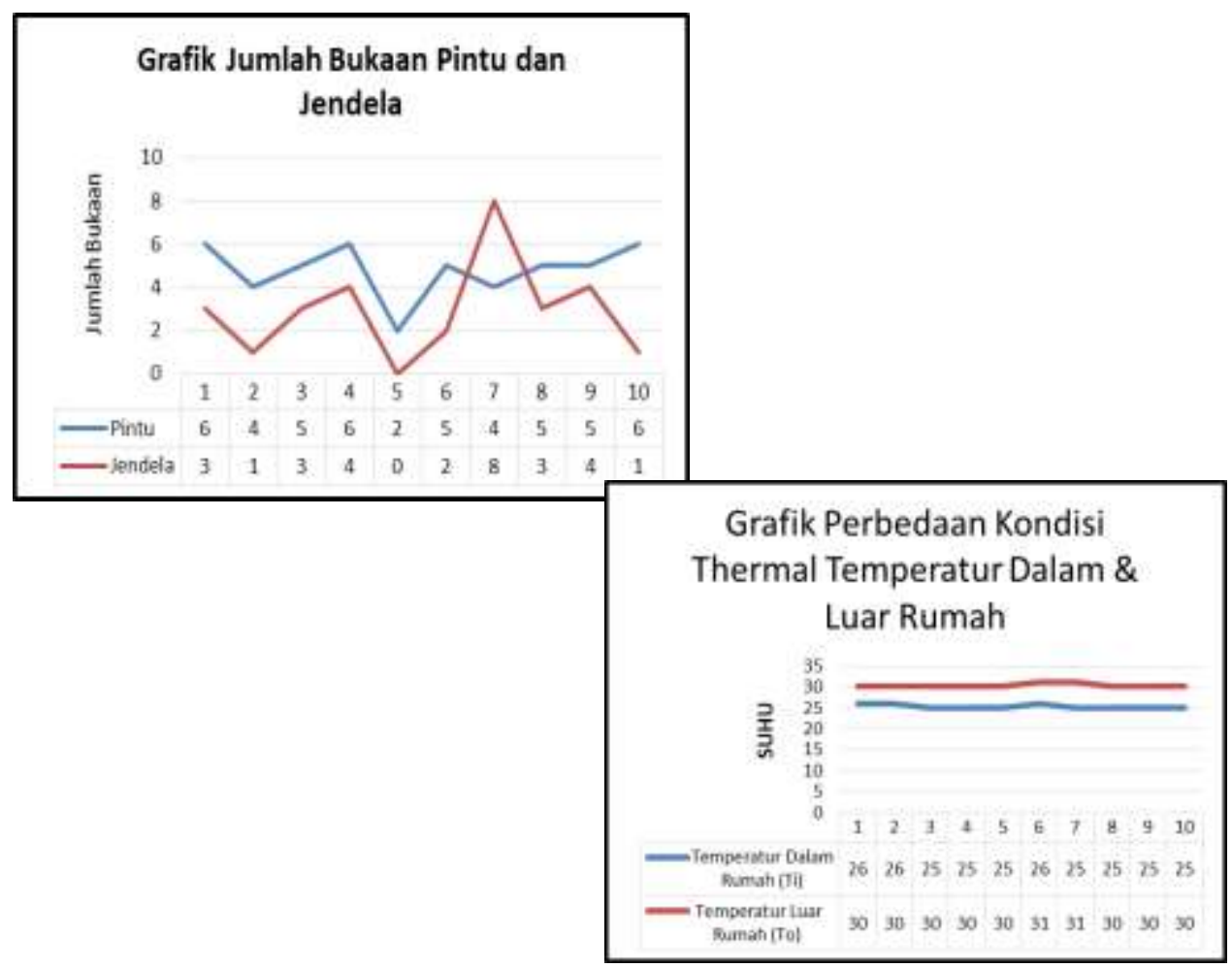

Pengaruh jumlah bukaan pada rumah sangat berpengaruh terhadap perbedaan suhu di dalam dengan suhu di luar rumah diakibatkan dari sirkulasi udara di dalam rumah yang tidak tersirkulasi dengan baik sehingga udara panas ketika siang hari tidak langsung masuk ke dalam rumah begitupun dengan angina dingin ketika malam hari tidak langsung masuk ke dalam rumah sehingga membuat perbedaan $\mathrm{Ti}$ dan To cukup signifikan.

Jumlah bukaan juga sangat berpengaruh terhadap kelembaban relatif di dalam dan diluar rumah. Menurut pengamatan yang dilakukan, terjadi perbedaan yang cukup signifikan terhadap kelembaban relatif di dalam dan diluar ruangan ketika siang hari dikarenakan jumlah bukaan. Mengingat kondisi iklim tropis di Indonesia memiliki tingkat kelembaban relatif yang cukup tinggi.

Pada pola pengoperasian singkat pawon berperan hanya sebatas untuk pengunaan ringan berkala, rata-rata pengoperasian dilakukan sebanyak 1-3 kali pengaktifan dengan jangka waktu tertentu kurang dari 30 menit. Pada pengoperasian sedang atau beberapa waktu, dapur cenderung digunakan untuk menghagatkan makanan hingga memasak makanan dengan waktu relatif singkat

PAWON: Jurnal Arsitektur, Nomor -- Volume --, Bulan Tahun, ISSN 2597-7636 
dari 30 hingga 60 menit. Pengoperasian berat yang berlangsung hingga lebih dari 1 jam, mengandalkan dapur untuk bekerja secara maskimal dan intensif, sehingga menaikan suhu disekitar secara signifikan. Namun penggunaan lebih dari satu jam hanya di saat tertentu saja jika warga sedang ada acara tahlil, syukuran, dan makan bersama.

\section{KESIMPULAN}

Dapur tersebut masih menjadi alat utama untuk kebutuhan masak memasak warga, walaupun sebagian besar warga telah mengenal kompor gas. Dengan presentase hampir $90 \%$ warga yang menggunakan dapur, dapur memiliki fungsi lain seperti untuk berkumpul dengan keluarga dan tetangga hingga sebagai salah satu elemen penghangat ruangan ketika suhu lingkungan dingin.

Dapur sebagai elemen penghangat ruangan dapat maksimal menghangatkan jika memenuhi kriteria tertentu. Kriteria tersebut adalah posisi dapur terhadap bangunan utama yang terletak satu atap dengan bangunan utama. Hasil pengamatan yang telah dilakukan membuktikan bahwa hawa panas yang ditimbulkan dapur dapat maksimal menghangatkan ruangan jika dapur berada satu atap dengan bangunan utama dengan sensasi termal yang dirasakan saat dapur digunakan.

\section{DAFTAR PUSTAKA}

1. Dewi, Pancawati. 2010. Peran Perapian Dalam Rumah Tinggal Masyarakat Tengger.

2. Evans, Martin. 1980. Housing, Climate and Comfort. The Architectural Press. London.

3. Givoni, B. 1998. Climate Considerations in Building and Urban Design. Van Nostrand Reinhold. New York.

4. Indeswari, Ayu. 2013. Dinamika Dalam Pemanfaatan Ruang Bersama Pada Perrmukiman Madura Medalungan Di Baran Randugading Malang. Arskon Jurnal Arsitektur dan Konstruksi. Volume 2 No. 1.

5. Kartono, J. Lukito. 2005. Konsep Ruang Tradisional Jawa Dalam Konteks Budaya. Universitas Kristen Petra Surabaya

6. Lippsmeier, Georg. 1997. Bangunan Tropis. Penerbit Erlangga. Jakarta

7. Nuryanto. 2011. Fungsi Dan Makna Pawon Pada Arsitektur Rumah Tradisional Masyarakat Sunda. Universitas Brawijaya. Malang

8. Prijotomo, 1999. Griya Dan Omah, Penelusuran Makna dan Signifikasi di Arsitektur Jawa. Universitas Kristen Petra Surabaya

9. Rapoport, Amos. 1982. The Meaning of The Built Environment. London

10. Santosa, M. Nastiti, S. dan Sudarmo, E. 1987. Aspek Kepadatan Dan Bentuk Lingkungan Permukiman pada Penggunaan Energi Alam. Laboratorium Sains Bangunan. Jurusan Arsitektur. ITS. Surabaya.

11. Sasongko, Ibnu. 2005. Pembentukan Struktur Ruang Permukiman Berbasis Budaya (Studi Kasus: Desa Puyung - Lombok Tengah). Universitas Kristen Petra Surabaya 
12. Van Straaten, JF. 1980. Passive Cooling and Heating Through Building Design. Dalam seminar Passive and Low Energy Cooling, Heating and Dehumidification. University of Miami. Florida.

13. Waani, Judy O. 2012. Teori Makna Lingkungan Dan Arsitektur. Media Matrasan vol. 9 no. 1. 